\title{
PENGARUH ANGIN TERHADAP PERTUMBUHAN AWAN HUJAN DI DAS WADUK PLTA KOTA PANJANG
}

\author{
Erwin Mulyana \\ UPT Hujan Buatan BPPT
}

\begin{abstract}
Abstrak
Telah dianalisis hubungan antara pembentukan awan hujan dengan kecepatan angin di Waduk PLTA Kota Panjang. Penelitian ini menggunakan data angin dan kelembaban udara dari NCEP reanalysis, data angin hasil pengukuran dengan pilot balon, pengamatan awan dengan pesawat terbang serta data hujan dari penakar hujan terpasang serta data hujan TRMM. Hasil analisis menunjukkan kejadian hujan sangat terkait dengan besarnya kecepatan angin di lapisan atas. Kejadian tidak ada hujan pada tanggal 12 - 19 April 2013 berhubungan dengan tingginya kecepatan angin pada lapisan 700 - 600 mb yang merncapai 40 knot serta kelembaban udara kurang dari 60\%. Angin kencanag terkait dengan adanya pusat tekanan rendah di Samudra Hindia di sebelah barat Sumatera Barat. Sebaliknya pada tanggal 20 - 30 April 2013, ketika kecepatan angin jauh berkurang hingga di bawah 5 knot, terjadi peningkatan curah hujan di DAS Waduk PLTA Kota Panjang. Agin kencang pada lapisan 700 - 600 mb mengakibatkan pertumbuhan awan terganggu sehingga sulit membentuk awan hujan. Awan yang terbentuk umumnya berupa awan Stratocumulus dan Stratus yang tidak berpotensi hujan.
\end{abstract}

Kata kunci : Waduk PLTA Kota Panjang, curah hujan, kecepatan angin, pusat tekanan rendah, kelembaban udara.

\section{PENDAHULUAN}

Variasi hujan di Indonesia umumnya dipengaruhi oleh ENSO (Hendon, 2003; Aldrian et al, 2007; Qian, J., Robertson, A. W., \& Moron, V. ,2010), monsoon Asia-Australia (McBride 1987, Aldrian and Susanto 2003). Pola monsunal ini ditandai oleh perbedaan yang sangat tegas yaitu musim kemarau yang berkaitan dengan monsun Australia dan musim hujan yang berkaitan dengan monsun Asia. Dalam sekala yang lebih sempit, variasi hujan juga sangat bergantung kepada karakteristik topografi masing masing daerah (Qian, 2008).

Akhir-akhir ini semakin sering terjadi ketidak teraturan musim antara musim hujan dan musim kemarau. Kemarau panjang berdampak terhadap kurangnya sumber air di beberapa Pusat Listrik Tenaga Air (PLTA). Hal ini mengakibatkan berkurangnya pasokan listrik untuk masyarakat. Salah satu PLTA yang sering mengalami krisis air adalah PLTA Kota Panjang di Provinsi Riau. Waduk PLTA Kotapanjang merupakan salah satu dari sekian banyak reservoir yang berada di Pulau Sumatera, yang didesain dengan fungsi utama untuk keperluan PLTA.

Waduk PLTA Kotapanjang terletak di Kabupaten Kampar, Provinsi Riau, dengan luas genangan air 12.400 ha. Waduk yang selesai dibangun pada tahun 1997 ini sumber utama air waduknya berasal dari Sungai Kampar dan Sungai Batang Mahat. Waduk PLTA Kotapanjang mempunyai kapasitas tampung air sebesar 545 juta $\mathrm{m}^{3}$, dengan ketinggian muka air maksimum $85 \mathrm{~m}$ dpl (di atas permukaan laut) dan minimum 73,5 m dpl, serta rata-rata debit masuk per tahun sebesar $184,4 \mathrm{~m}^{3} /$ tahun. Waduk ini mendapat pasokan air utama dari Sungai Kampar Kanan dan Batang Mahat, bagian hulu di provinsi Sumatera Barat 
dan bagian hilir di Propinsi Riau. Produksi listrik rata-rata setahun sebesar 542 GWh, sehingga mempunyai peran yang cukup penting dalam sistem kelistrikan di wilayah Sumatera Bagian Tengah, khususnya wilayah Riau.

Secara klimatologis, bulan April adalah salah satu puncak musim hujan di DAS Waduk PLTA Kota Panjang. Namun pada bulan April 2013 terjadi penurunan curah hujan dibandingkan dengan pola historisnya pada bulan yang sama. Selain itu, terdapat 8 hari berturut turut pada bulan April 2013 tidak terjadi hujan di 10 lokasi penakar hujan yang terpasang di dalam DAS. Untuk itu pada tulisan ini akan dianalisis tentang kejadian tidak hujan tersebut dihubungkan dengan keadaan atmosfer saat itu. Parameter cuaca yang akan dianalisis adalah arah dan kecepatan angin pada beberapa lapisan ketinggian, kelembaban udara, serta kondisi awan di daerah penelitian. Analisis hujan TRMM juga dilakukan untuk melihat sebaran hujan yang terjadi.

\section{DATA DAN METODA}

Data yang digunakan dalam tulisan ini berupa data primer dan skunder. Data primer meliputi curah hujan dari penakar hujan, data angin atas, serta pengamatan awan secara visual dengan pesawat terbang Casa 212-200. Sedangkan data skunder berupa data harian arah dan kecepatan angin serta data harian kelembaban udara dari NCEP Reanalysis. Data angin pada level ketinggian tertentu diperoleh dengan menerbangkan pilot balon kemudian diamati dengan teodolit sehingga dapat diperoleh arah dan kecepatan angin pada setiap lapisan ketinggian yang telah ditentukan. Data hujan diperoleh dari 10 penakar hujan yang dipasang di dalama DAS Waduk PLTA Kota Panjang.

Pengamatan angin untuk level ketinggian tertentu dengan pilot balon dilakukan 4 kali sehari di Posmet Muaro Paiti. Sepuluh penakar hujan tersebar di dalam DAS Waduk PLTA Korta Panjang, yaitu di Koto Bangun, Muaro Paiti, Gunung Malintang, Pangkalan, Tanjung, Dusun Tigo, Bandur Picak, Batu Basurat, Dam site PLTA Kota Panjang, dan Posmet Muara Paiti.

\section{HASIL DAN PEMBAHASAN}

\subsection{Daerah Penelitian}

Daerah penelitian adalah DAS Waduk PLTA Kota Panjang yang terletak di Provinsi Sumatera Barat dan Provinsi Riau (lihat Gambar 1). Daerah tangkapan hujan yang alirannya masuk ke dalam waduk umumnya berada di Provinsi Sumatera Barat, sedangkan daerah genangan air waduk berada di wilayah Provinsi Riau. Batas DAS sebelah barat adalah pegunungan Bukit Barisan sedangkan batas DAS di sebelah utara, selatan dan timur berupa pebukitan yang tingginya lebih rendah bila dibandingkan dengan pegunungan Bukit Barisan. Luas badan air Waduk PLTA Kota Panjang sekitar 12.400 ha dengan kapasitas tampung air sebesar 545 juta $\mathrm{m}^{3}$. Rata-rata debit air yang masuk ke dalam waduk sebesar $184,4 \mathrm{~m}^{3}$ /tahun, dengan ketinggian muka air maksimum 85 mdpl dan minimum 73,5 mdpl. Waduk ini mendapat pasokan air utama dari Sungai Kampar Kanan dan Sungai Batang Mahat yang bagian hulunya berada di Provinsi Sumatera Barat. 


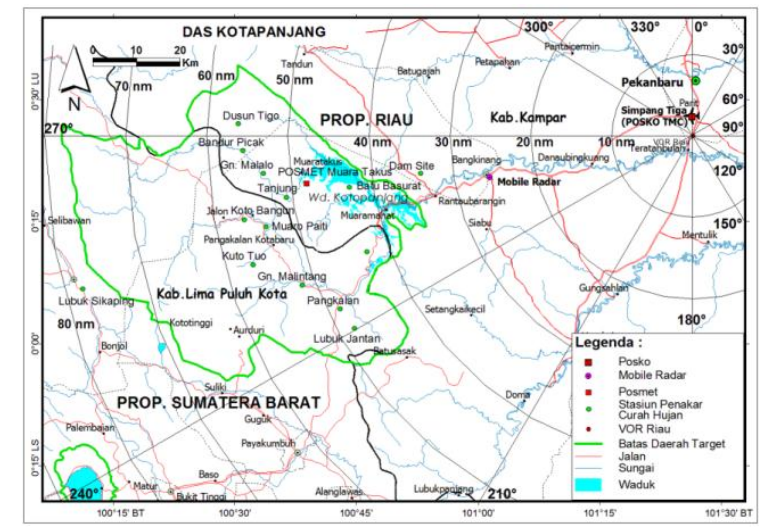

Gambar 1. Lokasi penelitian di DAS Waduk PLTA Kota Panjang

\subsection{Pola Hujan Bulanan}

Sehubungan dengan tidak tersedianya data time series curah hujan dari lokasi penakar hujan di dalam wilayah DAS Kotapanjang untuk jangka waktu yang cukup lama, maka pola hujan di DAS Kotapanjang dianalisis berdasarkan data TRMM (Tropical Rainfall Measuring Mission) sejak tahun 1998 2011. Data TRMM adalah data estimasi curah hujan berupa grid dengan resolusi spasial $0.25 \times 0.25$ derajat, yang diperoleh dari citra satelit yang dioperasikan oleh NASA (National Aeronautics and Space Administration).

Berdasarkan data TRMM, curah hujan bulanan di DAS Waduk PLTA Kota Panjang mempunyai pola bimodal yaitu dalam satu tahun memiliki dua puncak musim hujan. Puncak musim hujan berlangsung pada bulan Desember dan bulan April. Curah hujan rata-rata pada bulan Desember sebesar $342 \mathrm{~mm}$ dan pada bulan April sebesar $317 \mathrm{~mm}$. Sedangkan curah hujan terendah terjadi pada bulan Juni sebesar 168 $\mathrm{mm}$. Pola curah hujan dengan dua puncak musim hujan termasuk ke dalam pola equatorial (Aldrian, 2003). Rata-rata curah hujan bulanan dari bulan Januari sampai bulan Desember bisa dilihat pada Gambar 2.

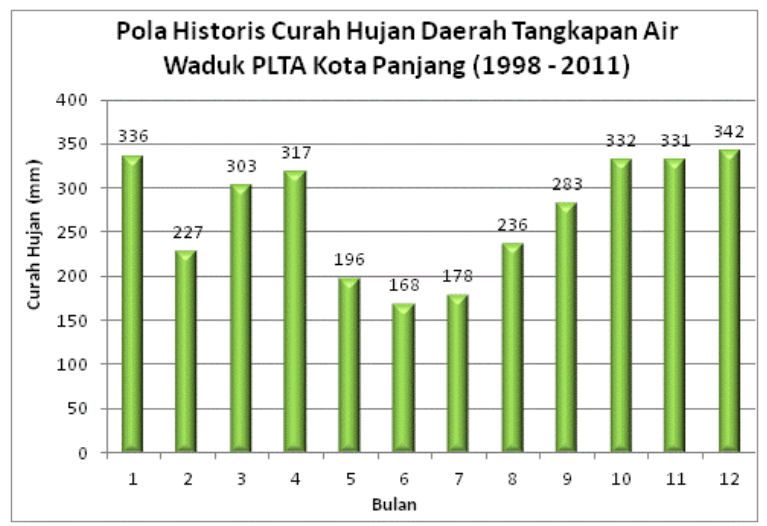

Gambar 2. Pola historis tahunan curah hujan di DAS Waduk PLTA Kota Panjang. (TRMM 1998-2011).

Bila dibandingkan dengan pola hujan bulanan, besarnya curah hujan pada bulan April 2013 masih di bawah nilai historis curah hujan pada bulan yang sama. Curah hujan historis pada bulan April adalah 317 mm, sedangkan curah hujan pada bulan April 2013 adalah $281 \mathrm{~mm}$. Besarnya curah hujan pada bulan Februari dan Maret 2013 juga di bawah nilai historis bulanannya. Sedangkan curah hujan pada bulan Januari 2013 berada di atas nilai rata-rata bulanannya. Secara umum curah hujan kumulatif selama bulan April 2013 di DAS Waduk PLTA Kota Panjang semakin ke timur nilainya semakin besar. 


\subsection{Curah Hujan Harian}

Penakar curah hujan manual yang dipasang di dalam DAS Waduk PLTA Kota Panjang berjumlah 10 buah yang lokasinya berada di Dusun Tigo, Bandur Picak, Gunung Malalo, Dam site, Tanjung, Batu Basurat, Kota Bangun, Gunung Malintang, dan Pangkalan (lihat Gambar 1). Sebaran penakar curah hujan berada di bagian tengah dan timur DAS Kota panjang sedangkan di bagian barat DAS tidak dipasang penakar hujan karena daerahnya sulit dijangkau.

Besarnya curah hujan harian di DAS Waduk PLTA Kota Panjang dari tanggal 5 s.d 30 April 2013 disajikan pada Gambar 3. Hujan harian tersebut merupakan hujan rata-rata wilayah yang berasal dari 10 penakar curah hujan yang dipasang di dalam DAS Waduk PLTA Kota Panjang. Selama periode tersebut total jumlah curah hujan wilayah di DAS Kota Panjang sebesar $188.4 \mathrm{~mm}$. Curah hujan terbesar terjadi pada tanggal 25 April 2013 sebesar $48.3 \mathrm{~mm}$. Secara umum pada awal bulan April hingga tanggal 11 April 2013 masih sedikit terjadi hujan. Selanjutnya kondisi atmosfer relative kering sehingga tidak terjadi hujan berturut-turut selama 8 hari yaitu pada tanggal 12-19 April 2013. Pada tanggal 20 April 2013 mulai terjadi hujan dan berlanjut hingga tanggal 30 April 2013. Catatan hujan harian di 10 penakar hujan yang dipasang di dalam DAS Waduk PLTA Kota Panjang disajikan pada Tabel 1.

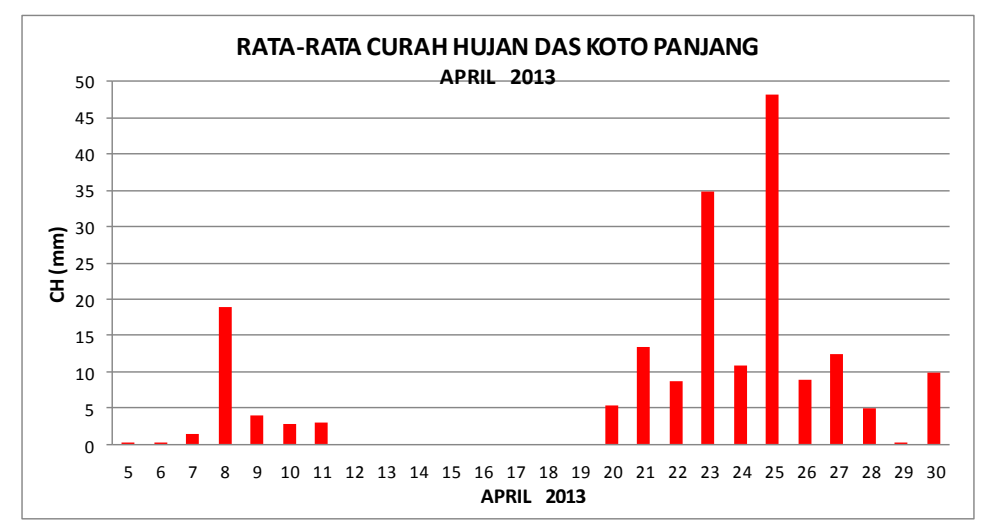

Gambar 3. Grafik curah hujan harian rata-rata dari 10 penakar yang terpasang di dalam DAS Waduk Kota Panjang pada bulan April 2013.

Tabel 1. Curah hjan harian dari penakar hujan yang terpasang di DAS Waduk Kota Panjang pada bulan April 2013.

\begin{tabular}{|c|c|c|c|c|c|c|c|c|c|c|c|c|c|c|c|c|c|c|c|c|c|c|c|c|c|c|c|}
\hline \multirow{2}{*}{\multicolumn{2}{|c|}{ Stasiun }} & \multicolumn{26}{|c|}{ APRIL } \\
\hline & & 5 & 6 & 7 & 8 & 9 & 10 & 11 & 12 & 13 & 14 & 15 & 16 & 17 & 18 & 19 & 20 & 21 & 22 & 23 & 24 & 25 & 26 & 27 & 28 & 29 & 30 \\
\hline \multicolumn{28}{|c|}{ DAS Kota Panjang : } \\
\hline 1 & Koto Bangun & 1.0 & 0.0 & 0.0 & 18.0 & 1.0 & 6.0 & 3.0 & 0.0 & 0.0 & 0.0 & 0.0 & 0.0 & 0.0 & 0.0 & 0.0 & 4.0 & 0.0 & 11.0 & 16.0 & 6.0 & \begin{tabular}{|l|}
61.0 \\
\end{tabular} & \begin{tabular}{|l|}
19.0 \\
\end{tabular} & 6.0 & 3.0 & 2.0 & 6.0 \\
\hline 2 & Muaro Paiti & 0.0 & 0.0 & 0.0 & 21.0 & 1.0 & 0.0 & 8.0 & 0.0 & 0.0 & 0.0 & 0.0 & 0.0 & 0.0 & 0.0 & 0.0 & 0.0 & 1.0 & 2.0 & 81.0 & 14.5 & \begin{tabular}{|l|}
44.0 \\
\end{tabular} & 5.5 & 6.5 & 9.5 & 0.0 & 8.5 \\
\hline 3 & Gn. Malintang & 0.0 & 0.0 & 9.0 & 49.0 & 17.0 & 0.0 & 6.0 & 0.0 & 0.0 & 0.0 & 0.0 & 0.0 & 0.0 & 0.0 & 0.0 & 25.0 & 2.0 & 0.0 & 28.0 & 3.0 & 25.0 & 6.0 & 2.0 & 0.0 & 0.0 & 3.0 \\
\hline 4 & Pangkalan & 0.0 & 0.0 & 5.0 & 9.5 & 12.5 & 7.5 & 1.0 & 0.0 & 0.0 & 0.0 & 0.0 & 0.0 & 0.0 & 0.0 & 0.0 & 1.0 & 24.5 & 2.5 & 55.0 & 55.0 & 58.0 & 5.0 & 12.0 & 0.0 & 0.0 & 1.0 \\
\hline 5 & Tanjung & 1.0 & 0.0 & 0.0 & 2.0 & 0.0 & & 0.0 & 0.0 & 0.0 & 0.0 & 0.0 & 0.0 & 0.0 & 0.0 & 0.0 & & 52.5 & 1.5 & 23.0 & 11.5 & 36.0 & 4.5 & 9.5 & 0.0 & 0.0 & 22.5 \\
\hline 6 & Dusun Tigo & 0.0 & 0.0 & 0.0 & 0.0 & 0.0 & 0.0 & & 0.0 & 0.0 & 0.0 & 0.0 & 0.0 & 0.0 & 0.0 & 0.0 & 13.0 & 22.0 & 30.0 & 14.0 & 2.0 & 52.5 & 2.5 & 13.5 & 0.0 & 0.0 & 0.0 \\
\hline 7 & Bandur Picak & 0.0 & 0.0 & 0.0 & 10.0 & 0.0 & 10.0 & 0.0 & 0.0 & 0.0 & 0.0 & 0.0 & 0.0 & 0.0 & 0.0 & 0.0 & 0.0 & & 24.0 & 34.0 & 0.0 & 66.0 & 25.0 & & 0.0 & 0.0 & \\
\hline 8 & Batu Basurat & 0.0 & 0.0 & 0.0 & 2.0 & & 0.0 & 0.0 & 0.0 & 0.0 & 0.0 & 0.0 & 0.0 & 0.0 & 0.0 & 0.0 & 0.0 & 17.0 & 0.0 & 6.0 & 6.0 & 48.0 & 10.0 & 18.0 & 14.0 & 0.0 & 13.0 \\
\hline 9 & Damsite PLTA & 0.0 & 1.0 & 0.0 & 58.0 & 4.0 & 0.0 & 0.0 & 0.0 & 0.0 & 0.0 & 0.0 & 0.0 & 0.0 & 0.0 & 0.0 & 0.0 & 0.0 & 13.0 & 29.0 & 0.0 & 40.0 & 6.0 & 38.0 & 17.0 & 0.0 & 25.0 \\
\hline 10 & Posmet Muaro Paiti & & & 0.7 & 20.0 & 1.0 & 2.0 & 9.5 & 0.0 & 0.0 & 0.0 & 0.0 & 0.0 & 0.0 & 0.0 & 0.0 & ttu & 1.5 & 2.1 & 63.0 & 10.5 & 52.0 & 5.0 & 6.5 & 6.0 & $\mathrm{ttu}$ & 10.0 \\
\hline \multicolumn{2}{|c|}{ Rata-rata Harian } & 0.2 & 0.1 & 1.5 & 19.0 & 4.1 & 2.8 & 3.1 & 0.0 & 0.0 & 0.0 & 0.0 & 0.0 & 0.0 & 0.0 & 0.0 & 5.4 & 13.4 & 8.6 & 34.9 & 10.9 & 48.3 & 8.9 & 12.4 & 5.0 & 0.2 & 9.9 \\
\hline
\end{tabular}

Sebaran estimasi akumulasi curah hujan TRMM tanggal 12-19 April 2013 ditunjukkan pada Gambar 4. Berdasarkan gambar tersebut terlihat akumulasi estimasi curah hujan di dalam DAS PLTA Kota Panjang dan sekitarnya kurang dari $5 \mathrm{~mm}$. Di bagian utara DAS jumlah hujan yang turun relatif lebih besar dbandingkan dengan curah hujan yang terjadi di bagian selatan. Estimasi hujan TRMM ini nilainya lebih tinggi dibandingkan dengan curah hujan yang tercatat di penakar. Pada tanggal tersebut seluruh penakar yang terpasang di dalam DAS PLTA Kota Panjang tidak menunjukkan adanya kejadian hujan. 
Selanjutnya pad atanggal 20-30 April 2013 terjadi peningkatan curah hujan di DAS Waduk PLTA Kota Pajang.

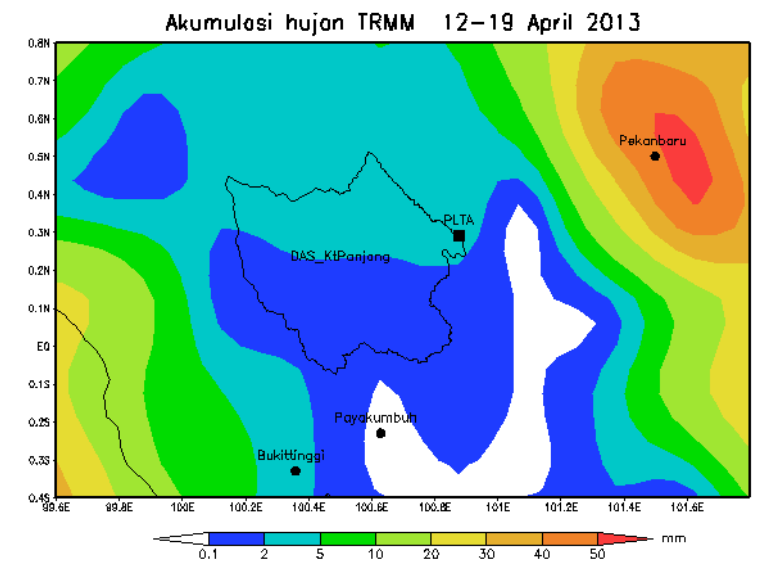

Gambar 4. Estimasi akumulasi hujan TRMM di DAS Kota Panjang dan sekitarnya pada tanggal 12-19 April 2013.

\subsection{Pengamatan Awan}

Pengamatan awan dilakukan secara visusl dengan menggunakan pesawat terbang casa 212-200. Selama kondisi kering yang berlangsung pada tanggal 12-19 April 2013, awan yang tumbuh di DAS Waduk Koto Panjang lebih didominasi oleh awan Sc. Awan Cu dan Sc umumnya berada di sekitar pegunungan Bukit Barisan di batas DAS sebelah barat. Awan yang terbentuk di dalam DAS Waduk Kota Panjang tidak berkembang menjadi awan hujan akibat angin kencang pada lapisan $700 \mathrm{mb}-600 \mathrm{mb}$. Gambar 5 menunjukkan awan Sc di sekitar pegunungan Bukir Barisan batas DAS sebelah barat yang diamati dari pesawat casa 212-200 pada ketinggian 10.000 feet. Di atas awan Sc ini didapati awan St dengan ketinggian dasar awannya sekitar 15.000 feet.

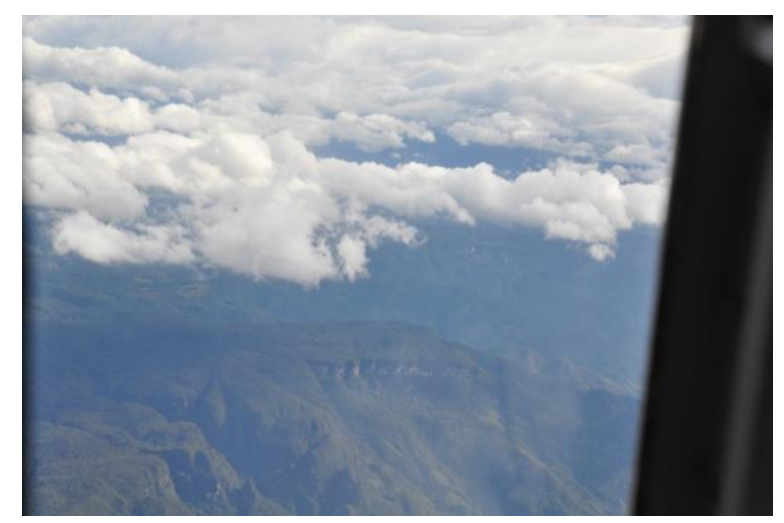

Gambar 5. Foto awan di sekitar pegunungan Bukit Barisan batas DAS sebelah barat pada tanggal 9 April 2013 jam 15.30 wib. Foto awan diambil dari pesawat Casa 212-200 pada ketinggian 10.000 feet.

\subsection{Arah dan Kecepatan Angin}

Berdasarkan data NCEP Reanalysis, pada bulan April 2013 di DAS Kota Panjang dan sekitarnya didominasi oleh angin baratan mulai dari lapisan $925 \mathrm{mb}$ sampai dengan lapisan $600 \mathrm{mb}$ seperti ditunjukkan pada Gambar 5. Dari gambar tesebut terlihat bahwa angin kencang terjadi pada tanggal 4-19 April 2013. Selanjutnya pada tanggal 20 - 30 April 2013 kecepatan angin berkurang hingga kecepatannya kurang dari 10 knot. Pada lapisan $850 \mathrm{mb}$ atau sekitar 5.000 feet, angin umumnya bertiup dri arah barat laut hingga barat daya dengan kecepatan bervariasi dari pelan hingga kencang. 
Kecepatan angin maksimum pada lapisan ini ditemukan pada tangal 6 April 2013 dengan kecepatan mencapai 30 knot.

Pada lapisan $700 \mathrm{mb}$ (10.000 feet) sampai dengan $600 \mathrm{mb}$ (14.500 feet), terdapat angin kencang pada tanggal 6 - 19 April 2013. Pada lapisan ini angin umumnya bertiup dari arah barat laut hingga barat dengan kecepatan bervariasi antara 10 - 30 knot. Kecepatan angin maksimum pada lapisan ini terjadi pada tanggal 7 April 2013. Secara keseluruhan, angin kencang pada lapisan $850 \mathrm{mb}-600 \mathrm{mb}$ terjadi pada tanggal 4 - 19 April 2013.

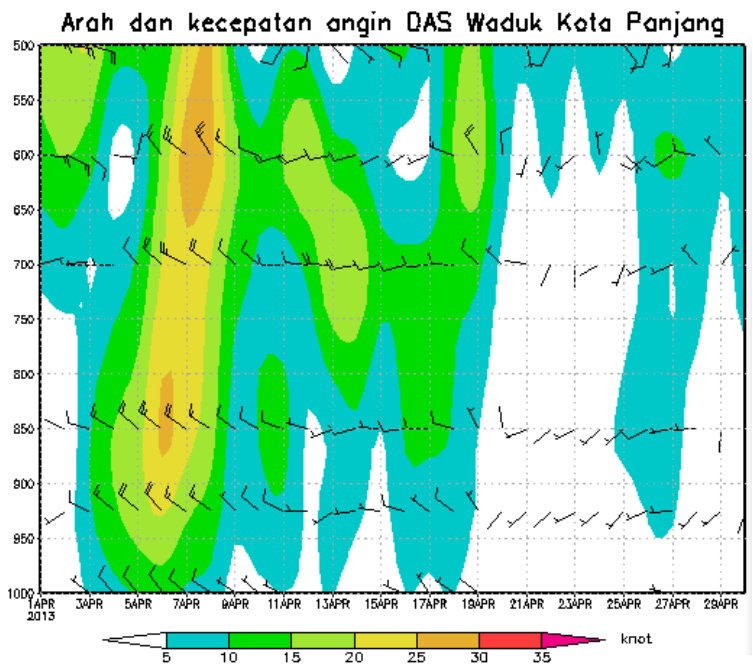

Gambar 5. Profil vertical arah dan kecepatan angin pada bulan April 2013 berdasarkan data NCEP

Reanalysis.

Hasil pengukuran angin pada berbagai lapisan ketinggian dengan pilot balon yang dilakukan di Posmet Muara Paiti menunjukkan pola yang sama dengan data NCEP Reanalysis. Lokasi Posmet Muara Paiti berada di dalam DAS Waduk PLTA Kota Panjang. Hasil pengukuran dengan pilot balon menunjukkan bahwa pada umumnya angin dengan kecepatan tinggi ditemui pada lapisan 5000 feet ke atas. Angin baratan dengan kecepatan cukup tinggi pada lapisan di atas 5000 feet umumnya terjadi pada tanggal 4-19 April 2013. Sebagai contoh, Tabel 2 berikut merupakan arah dan kecepatan angin di berbagai lapisan ketinggian hasil pengamatan dengan pilot balon yang dilakukan di Posmet Muara Paiti pada tanggal 13 April 2013 jam 13.00 wib.

Tabel 2. Arah dan kecepatan angina di Posmet Muara Paiti tanggal 13 April 2013 jam 13.00 wib

\begin{tabular}{|c|c|c|c|}
\hline $\begin{array}{c}\text { Level } \\
\text { (feet) }\end{array}$ & \multicolumn{2}{|c|}{ Arah } & $\begin{array}{c}\text { Kec. } \\
\text { (knot) }\end{array}$ \\
\hline 1.000 & 000 & $\mathrm{U}$ & 3 \\
\hline 2.000 & 340 & $\mathrm{U}$ & 4 \\
\hline 3.000 & 280 & $\mathrm{~B}$ & 8 \\
\hline 4.000 & 290 & $\mathrm{~B}$ & 10 \\
\hline 5.000 & 270 & $\mathrm{~B}$ & 9 \\
\hline 6.000 & 250 & $\mathrm{~B}$ & 12 \\
\hline 7.000 & 240 & $\mathrm{BD}$ & 11 \\
\hline 8.000 & 220 & $\mathrm{BD}$ & 18 \\
\hline 9.000 & 230 & $\mathrm{BD}$ & 23 \\
\hline 10.000 & 250 & $\mathrm{~B}$ & 37 \\
\hline 11.000 & 240 & $\mathrm{BD}$ & 41 \\
\hline 12.000 & 240 & $\mathrm{BD}$ & 34 \\
\hline 13.000 & 240 & $\mathrm{BD}$ & 42 \\
\hline 14.000 & - & - & - \\
\hline
\end{tabular}


Hasil pengukuran menunjukkan angin baratan mendominasi mulai dari level dekat permukaan hingga ketinggian 13.000 feet. Pada level permukaan sampai dengan ketinggian 5000 feet kecepatan angin masih 10 knot atau kurang. Makin ke atas kecepatan angin semakin kencang. Pada level ketinggian 6000 - 7000 feet mulai terjadi peningkatan kecepatan angin walaupun tidak terlalu besar. Lonjakan kecepata angin terjadi mulai level ketinggian 9.000 feet hingga ketinggian 13.000 feet. Pada level ketinggian 10.000 - 13.000 feet kecepatan angin lebih dari 30 knot. Kecepatan angin maksimum ditemukan pada lapisan 11.000 dan 13.000 feet, masing-masing dengan keceptan 41 knot dan 42 knot. Kecepatan angin yang sangat kencang pada level ketinggian 9000 - 13.000 feet mengganggu pertumbuhan awan yang terjadi di daerah tersebut. Kecepatan angin cukup tinggi di DAS Waduk PLTA Kota Panjang terkait dengan adanya pusat tekanan rendah di Samudera Hindia sebelah barat Sumatera Barat. Selanjutnya pada tanggal 20 - 30 April 2013, angin pada lapisan dekat permukaan hingga ketinggian $600 \mathrm{mb}$ kecepatannya berkurang hingga di bawah 5 knot. Pada periode tersebut di DAS Waduk PLTA Kota Panjang terjadi peningkatan curah hujan.

\subsection{Kelembaban udara}

Proses pembentukan awan tidak terlepas dari keberadaan uap air di atmosfer. Berdasarkan data harian NCEP Reanalysis pada bulan April 2013, kelembaban udara pada level dekat permukaan umumnya sekitar $90 \%$. Makin ke atas kelembaban udara semakin berkurang. Secara keseluruhan kondisi atmosfer kering pada level ketinggian $700 \mathrm{mb}-600 \mathrm{mb}$ ditemukan pada tanggal 8 - 23 April 2013. Kelembaban udara pada level dan tanggal tersebut umumnya di bawah $60 \%$. Selanjutnya ada peningkatan kelembaban nmulai tanggal 23 hingga aakhir bulan April 2013. Kelembaban udara pada berbagai lapisan ketinggian selama bulan April 2013 di DAS Waduk PLTA Kota Panjang dapat dilihat pada Gambar 6.

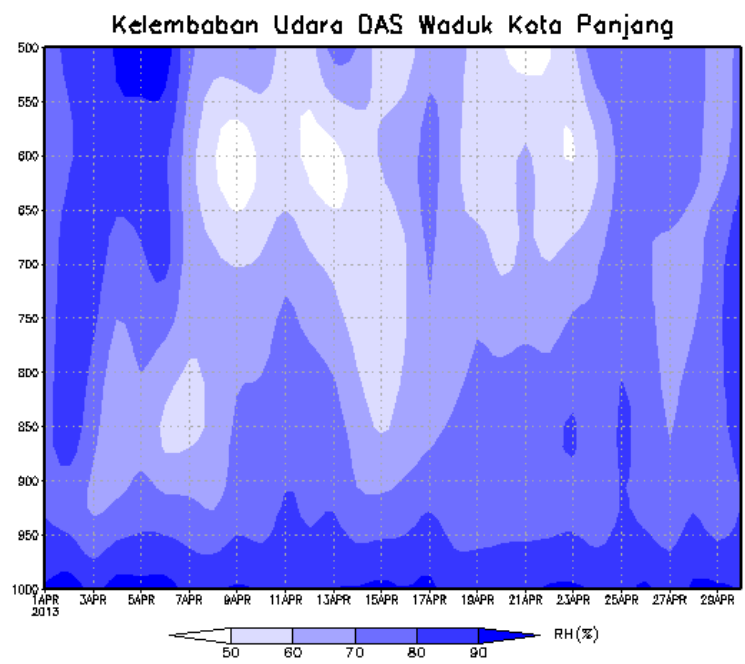

Gambar 6. Profil vertical kelembaban udara pada bulan April 2013 berdasarkan data NCEP Reanalysis.

Kejadian tidak ada hujan pada tangal 12-19 April 2013 di DAS Waduk PLTA Kota Panjang berkaitan erat dengan angin kencang pada lapisan 700-600 mb (10.000-14.500 feet) serta kelembaban udara rendah pada level ketinggian yang sama. Pada level ketinggian tersebut, kecepatan angin mencapai 30 knot, bahkan hasil pengukuran dengan pilot balon kecepatan angin mencapai 41 knot pada lapisan 11.000 feet. Pada level ketinggian yang sama, kelembaban udara di bawah $60 \%$. Walaupun kelembaban udara di dekat permukaan cukup tinggi dan berpeluang untuk terjadinya pembentukan awan, namun perkembangannya terhambat oleh angin kencang dan minimnya kelembaban udara di lapisan 700-600 mb. Kondisi ini mengakibatkan hujan sulit terjadi walaupun ada pertumbuhan awan. Umumnya awan yang terbentuk berupa awan Stratocumulus dan Stratus yang tidak berpotensi hujan. Kecepatan angin 
cukup tinggi di DAS Waduk PLTA Kota Panjang terkait dengan adanya pusat tekanan rendah di Samudera Hindia sebelah barat Sumatera Barat.

\section{KESIMPULAN DAN SARAN}

Bulan April merupakan salah satu puncak musim hujan di DAS Waduk PLTA Kota Panjang. Tidak adanya kejadian hujan di 10 penakar hujan di DAS Waduk PLTA Kota Panjang pada tanggal 12 - 19 April 2013 berhubungan dengan kecepatan angin dan kelembaban udara. Analisis angin dengan data NCEP reanalysis menunjukkan bahwa pada periode tersebut terdapat angin baratan dengan kecepatan mencapai 30 knot pada lapisan 700-600 mb atau setara dengan ketinggian 10.000 - 14.500 feet. Pengukuran angin dengan pilot balon pada periode yang sama juga menunjukkan adanya angin kencang pada lapisan 10.000 feet atau lebih. Pengukuran angin dengan pilot balon pada tanggal 13 April 2013 jam 13.00 wib menunjukkan angin baratan pada lapisan ketinggian 10.000 - 13.000 feet kecepatannya sebesar 30 - 40 knot. Selanjutnya pada tanggal 20 - 30 April 2013, angin pada lapisan dekat permukaan hingga ketinggian $600 \mathrm{mb}$ kecepatannya berkurang hingga di bawah 5 knot. Pada periode tersebut di DAS Waduk PLTA Kota Panjang terjadi peningkatan curah hujan. Kelembaban udara di lapisan 700 $600 \mathrm{mb}$ pada tanggal 12-23 April 2013 umumnya kurang dari $60 \%$. Sedangkan pada tanggal 24 hingga akhir bulan April 2013 terjadi peningkatan kelembaban udara. Dengan demikian dapat ditarik kesimpulan bahwa pembentukan awan hujan di DAS Waduk PLTA Kota Panjang berkaitan erat dengan besarnya kecepatan angin pada lapisan $700-600 \mathrm{mb}$. Agin kencang pada lapisan tersebut mengakibatkan hujan sulit terjadi walaupun ada pertumbuhan awan. Umumnya awan yang terbentuk berupa awan Stratocumulus dan Stratus yang tidak berpotensi hujan.

\section{PUSTAKA}

1. Aldrian, E., Dumenil Gates, L., \& Widodo, F. H., 2007: Seasonal variability of indonesian rainfall in ECHAM4 simulations and in the reanalyses: The role of ENSO. Theoretical and Applied Climatology, 87(1-4), 41-59.

2. Aldrian, E., and R. D. Susanto, 2003: Identification of three dominant rainfall regions within Indonesia and their relationship to sea surface temperature. Int. J. Climatol, 23, 1435-1452.

3. Hendon, H. H., 2003: Indonesian rainfall variability: Impacts of ENSO and local air-sea interaction. Journal of Climate, 16(11), 1775-1790.

4. McBride, J., 1987: The Australian summer monsoon. Monsoon Meteorology, C.-P. Chang and T. N. Krishnamurti, Eds., Oxford University Press, 203-231.

5. Ramage, C. S., 1968: Role of a tropical "maritime continent" in the atmospheric circulation. Mon. Wea. Rev., 96.

6. Qian, J., Robertson, A. W., \& Moron, V., 2010: Interactions among ENSO, the monsoon, and diurnal cycle in rainfall variability over java, indonesia. Journal of the Atmospheric Sciences, 67(11), 35093524 .

7. Qian, J., 2008: Why precipitation is mostly concentrated over islands in the maritime continent. Journal of the Atmospheric Sciences, 65(4), 1428-1441. 